\title{
$\mathrm{ICF}$ 를 활용한 효과적인 장애인 재활보조기기 신청 모바일 어플리케이션 개발 \\ 정봉근 $^{1^{*}}$, 이성아 ${ }^{1}$, 민세동 ${ }^{2}$ \\ ${ }^{1}$ 순천향대학교 의료과학대학 작업치료학과, ${ }^{2}$ 순천향대학교 의료과학대학 의료IT공학과
}

\section{Development of Mobile Application based on ICF(International Classification of Functioning, Disability and Health) for Provision of Assistive Devices for People with Disabilities}

\author{
Bong-Keun Jung ${ }^{1^{*}}$, Sung-A Lee ${ }^{1}$ and Se-Dong Min ${ }^{2}$ \\ ${ }^{1}$ Department of Occupational Therapy, College of Medical Science, Soonchunhyang University \\ ${ }^{2}$ Department of Medical IT Engineering, College of Medical Science, Soonchunhyang University
}

\begin{abstract}
요 약 본 연구에서는 국제기능장애건강분류체계인 ICF 코드와 국제표준위원회 재활보조기기 분류체계인 ISO 9999 의 코드 매칭을 활용한 재활 보조기기 사용자 맞춤형 정보 지원 시스템 구축에 활용할 수 있는 모바일 어플리케이션 과 시각장애인을 대상으로 한 사용성 평가를 조사하였다. 장애인의 일상생활에서의 어려움을 분석하여 기능을 보다 향상시키고 어려움을 경감시킬 수 있도록 개인적 특성과 기기의 장점을 서로 매칭시켜 주는 모바일 어플리케이션은 10 명의 시각장애인을 대상으로 사용성 평가를 실시한 결과 본 연구에서 개발된 ICF 코드를 활용한 모바일 어플리케 이션이 온라인 의 기존 재활보조기기 신청 방식보다 효과적인 것으로 나타났다. 결과 분석은 대응표본 $\mathrm{t}$-검정을 수행 하였으며 신뢰수준 $95 \%$ 를 기본값으로 하였다. 본 연구를 통해 도출된 프로토 타입 개발에 사용된 원천 기술은 온라 인 클라우드 정보 기반 서비스로 확장할 수 있으며 관련 산업 및 시장의 활성화를 촉진 시킬 수 있을 것이다.
\end{abstract}

\begin{abstract}
This study is aimed to introduce the newly developed mobile application for effective provision of assistive devices for people with disabilities in South Korea. By combining of ICF code and ISO 9999 code, more effective way of searching user fit assistive device information and selecting appropriate assistive devices were possible. 10 people with visual impairment were recruited for an usability testing. For the data analysis, paired t-test were used and confidence interval was 95\%. The result showed newly developed mobile application was more effective in comparison with on-line based assistive device information. The outcome of this study will enhance the provision of assistive devices for people with disabilities more effectively within better user understanding of their needs and compensate for their body function as well as environmental barriers.
\end{abstract}

Key Words : Assistive devices, ICF, Mobile application for assistive devices

\section{1. 서론}

\section{1 연구의 필요성 및 목적}

장애인과 고령자들이 사용하는 보조기기에는 보청기 및 휠체어 등 의료기기를 포함하여, 점자 키보드, 의사소 통 보완대체기기, 각종 소프트웨어와 같은 정보통신 보조
기기 프로그램, 그밖에 산소호흡기, 환자 운반용 리프트 등 중증 환자 및 장애인을 위한 보조기기에 이르기까지 다양한 품목을 포함하고 있다.

보조기기와 관련된 분류 체계 기준은 세계표준협회 ISO에서 제정한 ISO 9999, GMDN(Global Medical Device Nomenclature) 국제의료기기용어, SNOMED CT 
(Systematized Nomenclature of Medicine - Clinical Terms) 체계화된 의학용어 - 임상 용어집이 대표적이다 [1].

이들 보조기기의 개발, 구매 등을 위해 제품 관련 표준 분류 체계가 선진국에서는 국가 표준 등으로 제정되어 있어 보험 급여 및 재활보조기기 지급에 효과적으로 기 반 시스템을 마련하고 있는 반면 국내에서는 담당 부처 별, 기관별, 사용하는 용어 및 용어의 정의, 품목에 대한 분류체계가 서로 다르며 사용자 선정 등에 관한 기준이 상이하여 관련 산업체 및 소비자들에게 필요한 만큼의 정보를 제공하고 있지 못한 실정이다[2,3]. 이로 인해 소 비자는 재활 보조 기술 제품 구입 시 인터넷이나 개인용 단말기 등을 이용한 제품 정보를 검색하기보다 가족 등 주변 사람들이나 병원, 관공서 등 관련 서비스 담당자들 에게 제품 관련 정보 안내에 대부분 의존하고 있는 것이 현실이며 이는 관련 정보의 부족뿐만 아니라 접근성의 제한에 따른 것으로 보고되었다[4,5].

이들 보조기기의 공통점은 장애인과 고령자들의 일상 생활에서의 '기능' 을 보조하거나 향상시킴으로서 원하 는 활동을 회복 또는 지속적으로 수행 가능하도록 도와 준다는 것이다. 세계 보건기구 $\mathrm{WHO}$ 에서는 이와 같은 장 애인과 고령자 등 인간의 일상생활에서의 '기능'을 기술 하는 국제적인 표준 용어를2001년 제정하였다[6].

ICF(International Classification of Functioning, Disability and Health)는 인간이 어떻게 삶을 살아가는지 를 기술한다. ICF는 Fig. 1과 같이 건강과 관련하여 신체 의 구조 및 기능, 활동과 참여가 어떻게 연관되는지를 기 술할 수 있다. ICF는 인간이 생활하는 환경과 도구, 사회 시스템에 대해서도 기술할 수 있도록 체계적으로 정리된 표준 용어이다. 재활 보조기구는 이중 환경 요인 항목에 포함되어 알파벳 e로 시작되는 코드로 분류되어 있으며 다음 Table 1 과 같다.

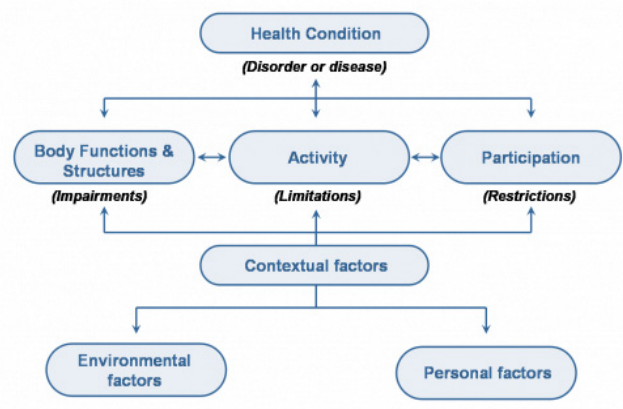

[Fig. 1] The concept of ICF(International Classification of Functioning, Disability and Health)
[Table 1] Assistive Device code (E) from ICF

\begin{tabular}{cl}
\hline ICF code & \multicolumn{1}{c}{ Description } \\
\hline \hline e115 & $\begin{array}{l}\text { Products and technology for personal use in } \\
\text { daily living }\end{array}$ \\
e120 & $\begin{array}{l}\text { Products and technology for personal use in } \\
\text { dailty living }\end{array}$ \\
e125 & $\begin{array}{l}\text { Products and technology for communication } \\
\text { e130 }\end{array}$ \\
e135 & Products and technology for education \\
\hline
\end{tabular}

Table 1에 따르면 ICF의 경우 재활보조기기를 e1151 "일상생활에서 사용하는 보조기구 및 기술" 로 정의하고 있고 e1251의 경우 “의사소통을 위한 보조기구 및 기술” 로 정의하는 등 제품 사용 목적에 따라 이를 6 가지 세부 분류 코드로 나누고 있으며 보조공학기기에 해당하는 코 드는 e1151 - e1351까지에 해당한다. 이들 e코드의 경우 [Fig. 2]와 같이 국제표준위원회 ISO 9999 재활보조기기 표준용어 1 단계 용어와 매칭되어 사용될 수 있다. ICF는 인간의 질병, 장애, 기능에 대한 단순한 분류체계라기 보 다는 인간의 작업수행에 영향을 미치는 다양한 요소들 인간의 기능과 직접적인 연관을 통해서 사회학적, 인구학 적 통계가 가능하도록 한다. 재활보조기기 관련 효과측정 을 주로 연구한 Schraner는 ICF코드를 직접 활용하여 재 활보조기기의 경제적 효과성에 대하여 분석하였다[4].

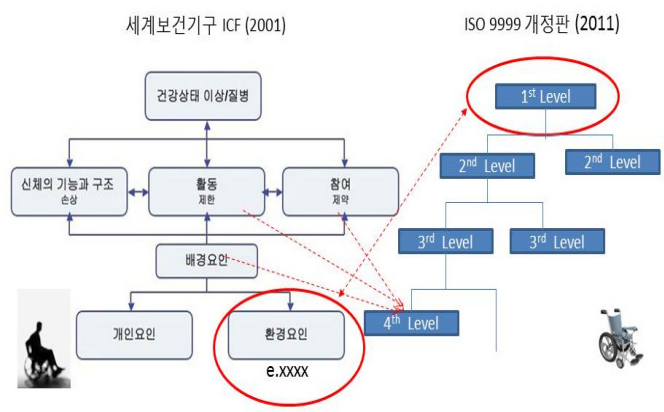

[Fig. 2] The relationship between ICF code and ISO 9999 code

이미 유럽 및 미국 등지에서는 ICF와 ISO 9999 코드 의 매칭 활용에 대한 제언이 문헌상에 많이 제시되어 있 으나 현재까지 ICF 표준 코드와 ISO 9999 코드결합에 관 한 알고리즘 및 코드 활용에 대한 구체적인 연구 결과는 전 세계적으로 발표되지 않았다[1,3].

무엇보다도 장애인을 위한 재활보조기기 선정에 있어 서 장애인 당사자가 요구하는 것을 정확히 파악하고 이 를 개선할 수 있는 재활보조기기를 정확하게 매칭 시키 기 위해서는 장애인의 일상생활 수행 정도 및 작업수행 
에서의 어려움을 제대로 파악해야 한다.

이와 같은 장애인의 개별적 특성과 활동참여 욕구, 재 활보조기기의 특성을 파악하기위해 대표적으로 Matching Person Technology 모델이 이론적으로 사용되고 있다[7]. 국내에서도 이와 같이 장애인에 대한 맞춤형 보조기기 지원을 위해 재활보조기기 및 ICF 분류체계에 대한 관심 도가 높아지고 있으며 국립재활원에서는 홈페이지를 통 해서 장애인들에게 제공되는 재활보조기구를 $\mathrm{ICF}$ (국제기 능장애건강) 분류 체계를 활용 정보를 제공하고 있다. 그 러나 2013년 현재까지 용어의 통일이나 표준화가 불충분 하며 사용자 및 공급자가 직접 정보를 입력하고 검색 가 능한 데이터 엔트리를 제공하고 있지 않아서 그 활용도 가 매우 낮은 수준으로 보고되고 있다[8].

정보화진흥원에서는 정보통신보조기기 신청을 위한 온라인 웹사이트(www.at4u.or.kr)를 운영하고 있으나 시 각장애, 청각 - 언어장애, 지체 -뇌병변의 3 가지 장애 유 형에 대해 질문의 경우 단순히 제품의 기능에 기초한 사 용자의 정보통신기기의 어려움에 관한 예/아니오 형식의 질문을 통한 개인별 맞춤형 보조기기를 선정하도록 지원 하고 있으며 이것은 질문과 해당 기기에 대한 $1: 1$ 링크 형식의 기본적인 형식을 따르고 있는 것으로 조사되었다. 이에 반하여 외국 선진국의 재활보조기기 분류체계 구축 및 활용 수준은 각종 의료보험 및 공적 부조에 활용될 수 있는 수준으로 그 활용도 측면에서 큰 기술적 차이를 보 이고 있다[2,3].

결론적으로 장애인에게 보다 효과적인 재활보조기기 를 지급하기 위해서는 기존의 시스템의 개선을 통해 장 애와 관련된 국제 분류 기준인 ICF 코드의 활용과 재활 보조기기의 제품 분류체계를 활용한 새로운 형태의 정보 제공시스템이 필요할 것이다.

\section{2 연구의 내용 및 방법}

본 연구에서는 장애인 재활보조기기 지급에 사용되는 재활보조기기 및 ICF 분류체계 활용의 국외 현황을 조사 분 석하여 재활 보조기기의 효율적인 소비자 구매 및 서비스 제공을 위한 정보 시스템 제공을 위한 모바일 어플리케이션 프로토타입을 1차 개발 하였고, 2차로 개발된 프로토타입에 대한 사용성 평가를 서울에 거주하는 10 명의 시각장애인을 대상으로 실시하였다. 개발된 모바일 어플리케이션 사용성 평가를 토대로 기존의 온라인 기반의 재활보조기기 신청 시 스템과의 사용성을 비교 분석하였다.

\section{2. 본론}

\section{1 국외 현황 조사}

모바일 프로토타입 개발에 앞서 국내외 현황 조사를 토대로 가장 효과적인 장애인 재활보조기기 정보 시스템 에 대한 분석을 진행하였다. 앞서 서론에서 소개한 국내 현황과 달리 해외에서는 보다 체계적이고 구체적인 재활 보조기기 맞춤형 지원이 조사되었다.

대표적인 예로 미국의 경우에는 의료, 직업재활, 특수 교육을 통해 주 정부에서 재활보조기기 지급 및 대여에 관한 지원체계가 구축되어 있으며, 그밖에 민간 의료보 험, 민간 자선단체 등에서 재활보조기기 구입을 지원하고 있다. 대표적으로 2000년 교육부 산하 국립 장애, 재활 연구소 NIDRR에서 대분류 10 개 품목, 중분류 71 개 품목, 소분 494개 품목으로 분류 책정하여 재활보조기기 관련 데이터베이스 Albedata를 개발하여 운용하고 있으며 일 본의 경우에는 의료보험, 연금보험, 산재보험 등 사회보 험 시스템과 국비와 지방비로 운영되는 신체장애자복지 법, 아동복지법 등에 의한 급여 지급 서비스가 마련되어 있다. 장애인용 재활보조기기의 정보 제공을 위해 일본 Techno-Aids 협회는 1995년 ISO 9999에 근간을 두고 CCTA (Classification Codes of Technical Aids) 분류코드 를 제작 하였다.

그리스, 덴마크, 스웨덴, 스위스 등 유럽국가에서는 재 활보조기구(Rehabilitation Technology Product)와 관련된 분류 체계 마련을 위해 TIDE (Technology Initiative for Disabled and Elderly People)를 1991년 조직하여 재활보 조기기 개발 및 유통 경로에 관한 단일화된 시장 기반을 마련하고 있다. 특히 관련 표준 정보 및 판매 등 유통 경 로에 대한 정보를 제공하는 창구 역할을 하고 있다.

독일 Rehadat의 경우 직업재활을 위한 정보 시스템으 로 독일 연방 정부 산하 노동 및 사회 정책부 주관으로 콜로네 경제 연구소(Cologne Institute for Economic Research)에서 설립하였다. 이 시스템의 경우 ISO 9999에 기반을 두고 독어 및 영문으로 검색 기능을 제공하고 있 으며 제품의 설명이나 기능은 직접 영문으로 번역하였거 나 통역 프로그램을 사용하여 정보를 제공하고 있다. 약 2 만 여종의 재활보조기기 중 독일에서 직접 구매 및 사용 이 가능한 제품을 포함하고 있으며 집안 청소 보조도구 를 비롯하여, 의수족 보조기, 장애인용 작업 시설 및 공정 도구 등을 포함하고 있다. 생산업체 및 유통업체에 대한 정보뿐만 아니라 가격 및 기술적인 설명과 의료보험으로 어떻게 지원을 받을 수 있는지에 대한 설명이 함께 포함 되어 있다[Fig. 3]. 


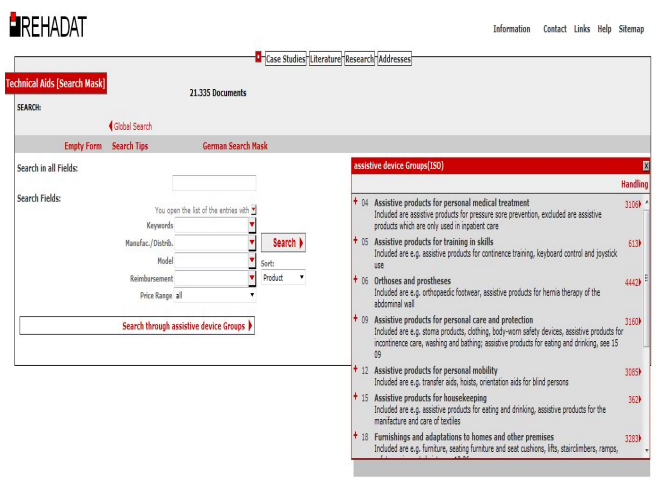

[Fig. 3] German Assistive Device Database Rehadat

네덜란드의 경우 3 개의 대표적인 재활보조기기 검색 정보 툴을 사용하고 있다. 민간 회사인Handy-Brains 에서 HANDY-WIJZER라는 웹 기반의 데이터베이스를 구축하 여 재활보조기기 품목별 정보를 제공하고 있다[Fig. 4]. 네덜란드뿐만 아니라 벨기에 재활보조기기 관련 전문 의 료 인력이 직접 사용하는 데이터베이스로 네덜란드어로 정보를 제공한다. 제품등록 회사들이 일정 부분 비용을 납부하면서 제품의 기능적 정보, 기술 정보 및 국제적 기 준 부합 정도, 부가 옵션 제공, 사진 정보를 제공한다. 법 률 및 관련 정책에 관한 정보제공, 품질 관리 및 ISO 9999 코드 및 키 단어 검색을 통해 관련 상품 검색이 가 능하다.
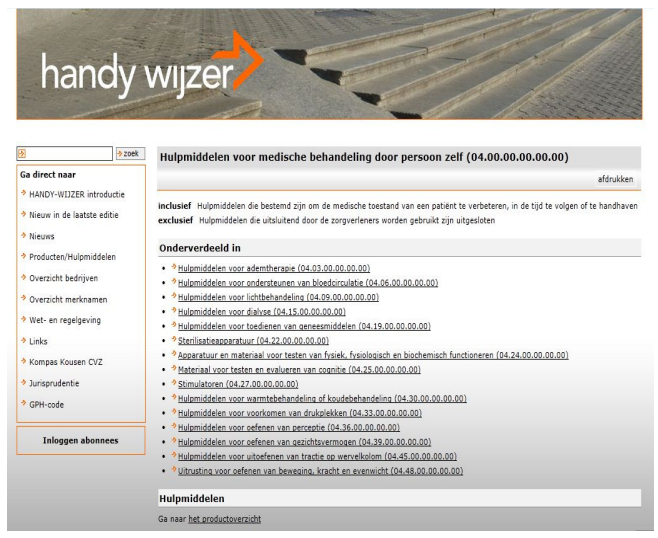

[Fig. 4] Netherlands Assistive Device Database HANDY-WIJZER

Hulpmiddelenwijzer라고 불리는 네덜란드 재활보조기 기 데이터베이스 제품 선택 후 세부 기능 및 기술 사항, 지급 유무 정보 열람 가능하다. 활동 및 참여 등 단어 검 색을 통해서 관련 상품 검색 가능하다.
또 다른 정보 검색 창인 Cliq(Classification with IQ)의 경우 네덜란드에서 개발된 재활보조기기 관련 세부 분류 정보 창 ISO 9999 의 6개 코드 입력을 통해서 관련 상품 검색, 제품의 의도하는 기능에 대해서 별도로 검색 가능 하도록 만들어져 있다[Fig. 5].

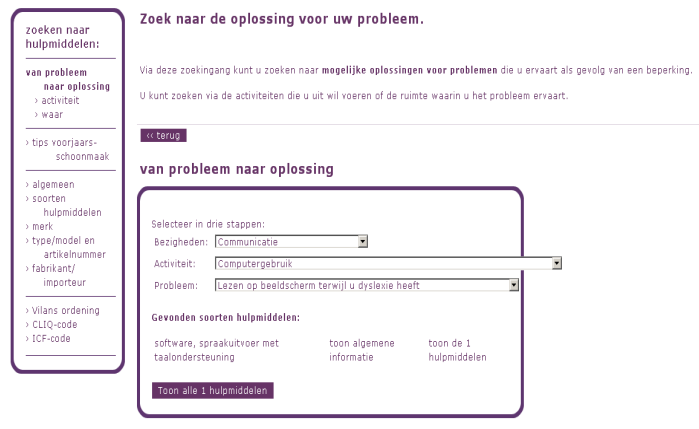

[Fig. 5] Netherlands Assistive Device Search Tool Cliq

결론적으로 국내 장애인의 경우 선진국과 비교했을 때 장애로 인한 기능에 맞춤식 보조기기 지원이 제대로 이 루어지지 않고 있음을 확인하였으며 외국에서는 장애인 들의 맞춤식 보조기기 지원을 위한 정보 제공이 보다 체 계화 되어 있음이 조사되었다. 국내에서도 국제 사회에서 통용되는 표준 용어 및 정의를 사용한 장애인 재활보조 기기 지원 및 제품 정보, 제품 품목별 표준 등록이 이루 어져야 하며 그 중에서 용어의 정의에 관한 부분은 점차 고조되는 인구 고령화, 국민 건강 증진 및 삶의 질 향상 을 위한 국가 인프라 구축을 위한 상호 운용성 확보를 위 해 반드시 필요한 것으로 나타났다.

\section{2 프로토타입 개발}

본 연구에서는 국내외 장애인용 재활보조기기 관련 품 목 분류 및 지급 체계 등에 관한 이전 연구 결과들을 바 탕으로 국내 상황에 적합한 재활보조기기 품목분류 데이 터베이스 구축을 위한 프로토타입을 개발하였다. 현재 온 라인을 통한 지급 신청 및 평가 심사가 이루어지고 있는 정보통신 보조기기 품목에 대하여 정보화진흥원 홈페이 지에 공개되어 있는 품목을 대상으로 사용자가 직접 신 청 및 열람이 가능한 모바일 어플리케이션을 최종 개발 하였다.

\subsection{1 개발 개요}

본 연구에서 개발한 모바일 어플리케이션은 기존의 온 라인 기반의 정보통신보조기기 품목별 정보 제공의 틀을 
벗어나 모바일 기기에서 semantic search engine algorithm을 사용하여 직접 사용자가 자신의 신체적 기 능, 활동 및 참여의 제한을 선택하고 이를 경감하거나 보 조할 수 있는 맞춤식 보조기기를 선별 검색할 수 있도록 설계하였다.

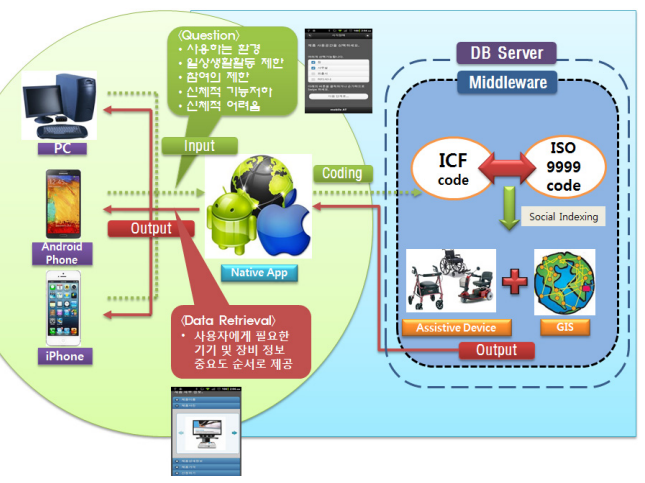

[Fig. 6] System Block Diagram of Newly Developed Mobile Application for AT provision

Fig. 6에서는 ICF 코드와 ISO 9999 코드에 대한 Data mining 기법을 통해 서버 내의 미들웨어에서 필요한 정 보를 어떻게 전송하는지 시스템 블록 다이어그램을 도식 화하였다.

본 연구에서는 모바일 어플리케이션에 활용할 데이터 알고리즘 개발에 두 가지 모델을 적용하여 제품 및 기술 에 대한 직접적인 정보 제공과 더불어 관련 기술 및 제품 의 시장을 예측할 수 있도록 구성하였는데 첫 번째로 설 명적 모델은 제품을 사용하는 사용자들의 특성이나 재활 보조기기를 사용하는 목적, 제품의 특정 및 제품을 사용 할 수 있는 환경, 구매 비용 등에 대한 단순한 정보에 초 점을 맞추었고, 두 번째 예측모델은 제품이 어떤 대상자 에게 얼마만큼의 효과를 가져 올 수 있는지 예측 가능하 도록 구성하였다.

두 가지 모델의 장단점을 파악한 결과 국제 표준 용어 및 분류 체계에 근거한 재활 보조 기술 산업 품목 개발 및 품목 관련 정보 활용을 위한 정보 처리 시스템 프로토 타입을 개발할 수 있었으며 제품 사용자 정보를 토대로 한 맞춤형 보조기기 선별을 위한 국제기능장애분류 코드 ICF 및 ISO 9999매칭 알고리즘 을 개발하였다[Fig. 7].

Fig. 8에서와 같이 사용자가 자신의 장애 유형의 선택 을 굳이 하지 않더라도 신체 및 활동 영역에 기능적 제한 을 지닌 영역을 입력함으로써 장애 유형에 적합한 보조 기기를 선별할 수 있도록 설계하였다.

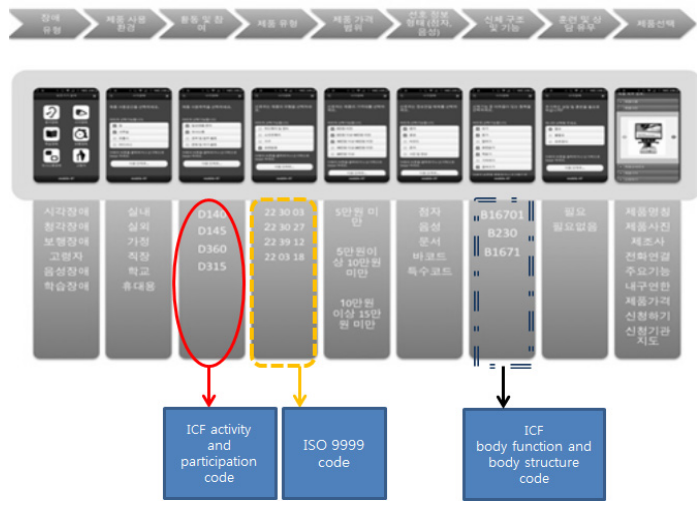

[Fig. 7] The Feature of Storyboard showing ICF code and ISO 9999 code matching throughout the system

이와 같은 기술은 현재 까지 적용된 사례가 없으며 세 계 최초로 세계보건기구에서 2001년 제정한 ICF 국제기 능건강장애 분류 코드와 보조기기 국제표준인 ISO 9999 코드를 직접 매칭 시켜서 사용자의 정보에 기반 한 맞춤 식 보조기기 선택이 가능하도록 지원하는 형태이다. 장애 인 사용자는 직접 모바일 기기에서 상담자에게 관련 정 보를 송출하고, 가까운 신청기관을 찾아갈 수 있도록 GIS 정보 또한 지원하고 있다. 모바일 앱에 포함된 모든 문자 및 그림 정보는 시각장애인이 청취할 수 있도록 코딩하 여 안드로이드 및 IOS에서 화면 읽기 프로그램을 통해 접근 가능하도록 설계하였다.

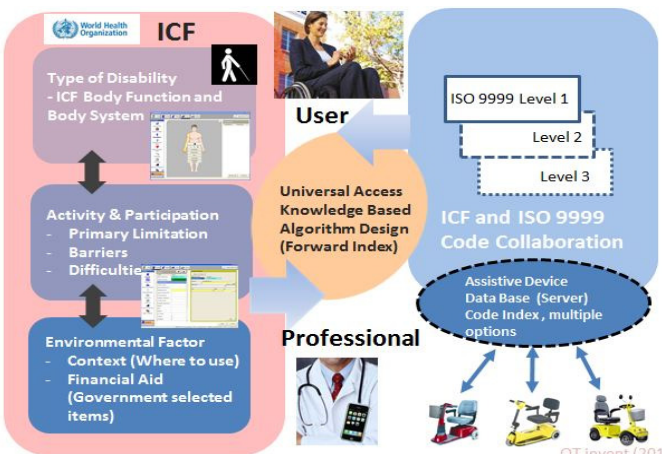

[Fig. 8] The System Feature showing ICF code and ISO 9999 code matching through middleware and database server

\subsection{2 기술 세부 정보}

HTML5, CSS3, jQuery 기술을 사용하여 특정 장치에 종속되지 않는 WebApp 형태의 모바일 어플리케이션 을 최종 제작하였다. iPhone과 Android Phone에서 모두 사 용할 수 있을 뿐만 아니라 $\mathrm{PC}$ 의 웹브라우저에서도 사용 
할 수 있다는 장점을 가지고 있다. 웹 어플리케이션을 iPhone과 Android Phone 전용의 Native 어플리케이션으 로 각각 변환하여 사용함으로써 어플리케이션의 기계접 근성에 대한 성능을 향상시켰다.

사용자의 보조기기 사용 목적 및 환경 등을 적절한 질 문을 통해서 응답을 유도하였고 답변 항목은 개별 ICF 코드로 분류되도록 설정하였다. 데이터에 저장되어 있는 품목 기기별 사용 목적에 맞는 ICF 코드가 자동적으로 사용자의 응답에 따라 매칭되도록 설계하였으며 이는 Fig. 7에 제시된 예와 같이 순서대로 작동하도록 설계 하 였다.

데이터베이스로 접속하기 위해서 JSON의 데이터 구 조를 사용하여서 기존의 XML 보다 더 빠르고 쉽게 데이 터를 처리할 수 있도록 제작하였으며 어플리케이션에서 제품 정보를 얻어오기 위해 서버에 있는 미들웨어(스크 립트 언어로 되어 있음)가 어플리케이션에서 입력된 정 보를 처리한 후 가장 적합한 보조기기를 찾아 최종 정보 를 다시 어플리케이션으로 전송 하도록 설계 하였다.

\section{3 개발 기술에 대한 사용성 평가}

\subsection{1 연구대상}

본 연구의 대상자는 전맹 시각장애 1 급 판정을 받은 20세 이상 성인 남녀를 대상으로 하였다. 2013년도 정보 통신보조기기 보급사업 기간 동안 정보통신보조기기 신 청에 관심을 가지고 있는 서울시 거주 10 명의 시각장애 인을 지역 시각장애인협회로부터 추천받아 이 중 10 명의 대상자를 선정하였다. 10 명의 사용성 평가 대상자는 기 존의 모바일 어플리케이션 사용성 평가연구[11]에서 제 시한 5 - 10명의 모집 집단수를 적용하였고 본 연구에 참 여한 10 명의 시각장애인들은 모두 개인 휴대용 스마트폰 을 사용하였고 보이스오버와 같은 화면 읽기 프로그램을 통해 인터넷 접속에 익숙한 사용자들이었다.

\subsection{2 연구도구}

사용성 평가는 보조기기 만족도 사용성 평가에 널리 사용되는 QUEST 2.0 한글 버전을 사용하였다[11].

QUEST 2.0은 총 12개 항목으로 보조기구의 만족도를 평가하는 8 개 항목과 이와 관련된 서비스의 만족도를 평 가하는 4 개 항목으로 구성되어 있다. 각 항목은 5 점 척도 를 사용하여 개인이 만족도 평가에서 매우 불만족한 경 우 '1점', 매우 만족한 경우 ‘5점'으로 표기한다.

본 연구에서는 QUEST 2.0 에 포함된 12 개 문항의 기 기에 대한 만족도 설문 중 본 연구에서 개발된 모바일 어 플리케이션에 해당하는 항목인 (1)제품의 조절, (2)용이,
(3)효과 세 가지 항목만을 평가하였으며 신청에 소요되는 시간을 별도 항목으로 측정하였다.

\subsection{3 실행 및 평가}

사용성 평가는 2013년 5월 15일부터 6월 15일까지 4 주 동안 진행되었으며 기존의 온라인을 통한 정보통신보 조기기를 신청하는 방법과 본 연구에서 개발된 모바일 어플리케이션을 사용하는 방법 두 가지를 각각 별도로 시행하고 각각 방법에 소요되는 시간을 측정하였으며 각 프로그램의 실행 후에 바로 사용성 평가를 진행하였다. 사용성 평가는 평가자가 질문을 읽고 연구 대상자의 응 답을 대필하였고 연구 책임자의 감독 하에 개별 평가 및 설문 조사가 진행되었다.

\subsection{4 자료 분석방법}

수집된 자료의 결과 분석에는 윈도우용 IBM SPSS Statistics 21 를 사용한 대응표본 t-검정을 수행하였으며 신뢰수준 $95 \%$ 를 기본 값으로 하였다.

\subsection{5 사용성 평가결과}

기술에 대한 사용성 평가 결과는 아래 Table 2 와 같다.

[Table 2] The result of usability test of newly developed mobile application for AT provision using ICF and ISO 9999 code algorithm

\begin{tabular}{ccccc}
\hline $\begin{array}{c}\text { K-QUEST 2.0 } \\
\text { items }\end{array}$ & $\begin{array}{c}\text { mobile } \\
\text { application }\end{array}$ & on-line & $\mathrm{t}$ & $\mathrm{p}$ \\
\hline \hline Adjustment & $4.50 \pm .53$ & $3.40 \pm .70$ & 3.97 & $.003^{* *}$ \\
Conformability & $4.60 \pm .52$ & $3.40 \pm .52$ & 4.81 & $.001^{* *}$ \\
Effectiveness & $4.00 \pm .00$ & $3.20 \pm .92$ & 2.75 & $.022^{*}$ \\
& $395.00 \pm$ & $761.00 \pm$ & & \\
Time (Sec) & 66.57 & 113.04 & -7.21 & $.000^{* * *}$ \\
\hline
\end{tabular}

${ }^{*} \mathrm{p}<.05, * * \mathrm{p}<.01, * * * \mathrm{p}<0.001$

$\mathrm{ICF}$ 를 활용한 모바일 어플리케이션을 사용한 결과와 온라인 웹사이트를 사용한 결과가 Table 2에서와 같이 조 절 $(\mathrm{p}<.01)$, 용이 $(\mathrm{p}<.01)$, 효과 $(\mathrm{p}<.05)$ 항목에서 모두 차이 가 유의하게 나타났다. 이는 기존 온라인을 통한 정보통 신보조기기 신청보다 개발된 모바일 어플리케이션을 활 용한 신청이 사용자에게 보다 유용한 것을 증명하였으며, 정보통신보조기기 신청에 걸리는 시간 역시 $\mathrm{p}<.001$ 로 차이가 유의한 것으로 모바일 어플리케이션의 사용이 신 청에 걸리는 시간을 단축시키는 것으로 조사되었다. 


\section{3. 고찰}

\section{1 프로토타입 개발}

본 연구에서 개발한 ICF 기반의 재활보조기기 지급을 위한 모바일 어플리케이션 프로토타입은 장애인들의 장 애 유형별 사용 제품 및 제품이 가지고 있는 특성을 미리 정보화 된 알고리즘에 따라 우선순위로 선별해 준다는 점에서 의의가 있으며 무엇보다도 세계보건기구 $\mathrm{WHO}$ 등을 통해 권고되고 있는 방식의 ICF를 활용한 서비스 모델 개발로서 그 의의가 있다고 하겠다.

장애인에게 필요한 재활보조기기의 품목이 한정되어 있으며 지급 대상에 대한 명확한 기준이 없기 때문에 매 번 장애인들은 본인이 원하는 보조기기의 신청에 제 3 자 의 도움을 받고 있는 것으로 조사되었다[12]. 이 연구에 따르면 정보통신 보조기기 사용 경험자의 $21.8 \%$ 가 가족 이나 친구로부터 관련 정보를 얻는다고 응답하였으며 $18.7 \%$ 가 사회복지사나 복지관에서 정보를 얻는 것으로 나타났다. 이는 일부 장애인의 경우 재활보조기기 신청 시에 자신에게 필요한 기기인지 혹은 제품의 특성에 대 해서 정확한 인지 없이 단순한 보조기기 보급 신청을 하 고 있다고 해석할 수 있다. 이와 같은 문제점을 해결하기 위한 방안으로도 정보통신 보조기기에 관한 정보 제공의 확대가 가장 우선시 되었다.

본 연구를 통해 개발된 ICF 코드와 ISO 9999 재활보 조기기 항목 표준 분류에 대한 매칭 시스템은 장애인이 전문적인 지식이나 제품에 대한 사전 정보가 없는 상태 에서도 본인의 문제점이나 필요시 되는 기능을 입력하여 그 기능을 보완 대체 할 수 있는 제품이나 기술을 모바일 어플리케이션 안에서 직접 선별하고 품목의 예를 제시할 수 있는 결과를 가져왔다.

또한 본 연구에서 개발된 프로토타입을 통하여 장애인 스스로가 본인의 문제점과 한계에 대해서 인지하고 이를 극복해 나가기 위한 자립의 의지와 목표설정을 보다 효 율적으로 할 수 있다는 점은 재활보조기기의 본래 목적 과 취지를 충분히 살려서 제품 보급 후에 미사용 등으로 인한 불필요한 예산을 절감하는 효과를 보일 것이다[13]. 개선사항으로는 정보통신보조기기에 한정되어 있는 Data Base를 보다 구체화 하고 포괄적으로 추가 연구가 진행 되어야 할 것이며 현재까지 ICF 및 ISO9999에 대한 한글 용어 표준화가 완성되지 않은 점을 고려할 때 국제적인 표준 용어의 한글화 작업 역시 서둘러야 할 것으로 판단 되어진다.

\section{2 사용성 평가}

본 연구에 참여한 시각장애인들은 평소에 스마트 폰을 자주 사용하였고 화면 읽기 프로그램 등의 사용에 다소 익숙했다고 판단이 된다. 하지만 평소에 스마트 폰의 사 용이나 인터넷 접속에 제한을 가지고 있는 사용자의 경 우에는 개개인의 차이에 따라 본 연구에서 개발된 프로 토타입의 사용에 걸리는 시간이나 만족도 역시 달라질 수 있을 것이라고 예상된다. 본 연구에서 사용성 평가 시 사용자의 스마트폰 사용에 대한 능력에 별다른 구분 없 이 조사가 진행되었고 대부분의 참여자가 인터넷 및 스 마트폰의 고빈도 사용자인 점을 감안하였을 때 결과 해 석에 일반화에는 다소 무리가 있을 것으로 사료된다. 추 가적인 사용성 평가를 통해서 장애 유형별 또는 스마트 기기 및 정보통신 사용 유무 및 빈번 도에 따른 시스템 활용의 수준 차이에 대해서도 추가적인 연구가 진행되어 야 할 것이다. 본 연구에서는 개발된 프로토타입의 기능 적인 측면과 효율성에 보다 초점을 맞추어 동일한 사용 자에게 서로 다른 환경이 주어 졌을 때 이에 대한 만족도 가 어떻게 달라지는지에 보다 초점을 맞추었다.

\section{4. 결론 및 제언}

재활보조기기 산업기술 분류 중 품목 분류에 대한 국 제적 경향을 파악하고 국내에 적합한 서비스 전달에 필 요한 데이터 엔트리 프로토타입을 개발해 보았다. 장애인 및 고령자를 위한 기술 및 제품의 개발과 상용화를 통한 경제적 이윤 창출을 위해서는 재활보조기기 용품의 시장 형성에 기반이 될 수 있는 종합적 $\mathrm{DB}$ 의 구축이 필수적 이다.

정부에서는 재활 보조 기술 사업이 추구하는 장애인의 삶의 질 향상을 위한 일관된 목표와 비전을 이루기 위해 장애인들이 소비자로서 직접 참여가 가능하고 사용할 수 있는 기기 및 제품의 검색 및 사용이 가능할 수 있도록 제품의 신뢰와 품질을 보증하는 규격화된 제품 등록 분 류체계의 확립이 반드시 필요하다. 본 연구의 결과물을 바탕으로 한국 장애인에게 적합한 재활보조기기 품목분 류 데이터를 마련하기 위해서 관련 하드웨어 및 어플리 케이션의 추가 구축이 요구되어진다.

본 연구를 통해 도출된 모바일 어플리케이션 프로토타 입 개발에 사용되어진 원천 기술을 활용하여 재활보조기 기뿐만 아니라 휠체어, 일상생활 보조용품, 건강 제품 등 고령 친화제품까지 보다 다양한 항목을 포함하는 모바일 어플리케이션 및 온라인 클라우드 정보 기반 서비스로 
확장할 수 있으며 관련 산업 및 시장의 활성화 하는데 기 여할 수 있을 것이다.

특히 이번 연구에서는 세계 최초로 WHO 에서 제정한 ICF 코드와 ISO 9999 (장애인 및 고령자를 위한 재활보 조기기)의 품목 코드 매칭을 구현하였으며 이 기술은 해 외 영문판 버전 등으로 출시하여 선진국 및 개발도상국 등에 효과적인 장애인 재활보조기기 지급 모델로 제시하 거나 국내 상품의 해외 시장 개척에 사용 될 수 있을 것 이다.

\section{References}

[1] World Health Organization. Building bridges between diseases, disabilities and assistive devices: linking the GBD, ICF and ISO 9999, 2010.

[2] Department of Health and Human Services, Durable Medical Equipment, Prosthetics, Orthotics, and Supplies (DMEPOS) Quality Standard, 2013

[3] Lenker JA, Shoemaker, LL., Fuhrer MJ, Jutai JW. Demers L, Tan CH, DeRuyer F. "Classification of assistive technology services: Implications for outcomes research", Technology and Disability, Vol. 24. pp.59-70. 2012.

[4] Yuk JH, Kim SN. "An International Comparative Analysis of Evaluating Internet Portal on Assistive Devices Information", Journal of Assistive Technology, Vol. 4, No. 1, pp.11-27, 2010.

[5] Kim IS, Oh DY, Kong JY, Kwon SJ, Nam SH, Park JY. "The Study of the Certification System for Managing Quality of Assistive Product", Journal of Rehabilitation Research, Vol. 15, No. 1, pp.121-147, 2011.

[6] World Health Organization. International Classification of Functioning, Disability, and Health, 2001.

[7] Scherer MJ, Craddock G. "Matching Person \& Technology (MPT) assessment process," Technology and Disability, Vol. 14, No. 3, pp.125-131. 2002.

[8] Korea Disabled People's Development Institute, Korea Assistive Technology Devices Products and Information based on Human, Activity, Assistive technology and Environment, 2012

[9] Schraner, I., De Jonge D, Layton N, Bringolf J, Molenda A. "Using the ICF in economic analyses of Assistive Technology systems: Methodological implications of a user standpoint", Disability and Rehabilitation, Vol. 30, No. 12-13, pp. 916-926, 2008. DOI: http://dx.doi.org/10.1080/09638280701800293

[10] Kaikkonen A, Kallio T, Kekalainen A, Kankainen A,
Cankar M. "Usability Testing of Mobile Application: A comparison between laboratory and field testing", Journal of Usability Studies, Vol. 1, pp. 4-16, 2005.

[11] Lee SH, Jung BK, Park SY. "Korean Translation and Psychometric Properties of Quebec User Evaluation of Satisfaction Assistive Technology 2.0", Journal of the Korea Academia-Industrial Cooperation Society, Vol. 14, No. 7, pp. 3284-3292, 2013.

DOI: http://dx.doi.org/10.5762/KAIS.2013.14.7.3284

[12] Rhee KM, "A survey study on the demands of information and communication assistive devices of persons with disabilities", The Journal of Special Education: Theory and Practice, Vol. 8, No. 4, pp. 427-49, 2007.

[13] Holzinger A, Searle G, Nischelwitzer A. "On some aspects of improving mobile applications for the elderly", Universal Access in Human Computer Interaction. Coping with Diversity Lecture Notes in Computer Science, Vol. 4554, pp. 923-932, 2007. DOI: http://10.1007/978-3-540-73279-2 103

정 봉 근(Bong-Keun Jung)

[정회원]

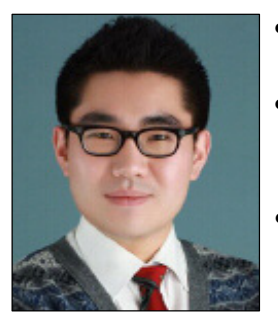

- 2011년 5월 : 미국 세인트루이스 워싱턴대학교(작업치료학 박사)

- 2011년 8월 2012년 1월 : 미 국 위스콘신대학 산업공학과 박 사후 연구원

- 2012년 3월 현재 : 순천향대 학교 의료과학대학 작업치료학 과 조교수

<관심분야>

재활공학, 장애정책, 운전재활

이 성 아(Seong-A Lee)

[정회원]

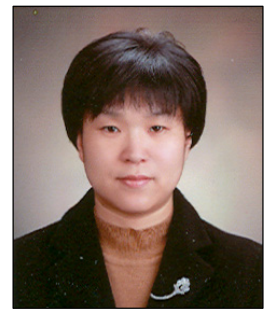

- 1996년 8월 : 연세대학교 보건대 학원 (보건학석사)

- 2008년 8월 : 가톨릭대학교 보건 대학원 (보건학박사)

- 2009년 3월 현재 : 순천향대 학교 의료과학대학 작업치료학 과 조교수

<관심분야>

인지재활, 노인작업치료, 작업치료평가 
민 세 동(Se-Dong Min)

[정회원]

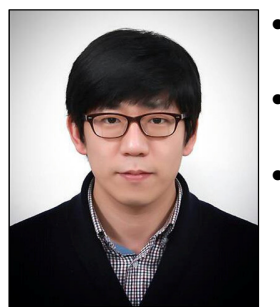

- 2010년 2월 : 연세대학교 전기전 자공학과(공학박사)

- 200년 3월 2012년 2월 : 삼성 전자 $\mathrm{DMC}$ 연구소 책임연구원

- 2012년 3월 현재 : 순천향대 학교 의료과학대학 의료IT공학 과 조교수

<관심분야>

모바일헬스케어, 웨어러블센싱, u-Health시스템 